\title{
PELATIHAN AKUNTANSI DAN MANAJEMEN SERTA MOTIVASI MOTHERCARE DI KABUPATEN MADIUN
}

\author{
Nanang Cendriono ${ }^{1)}$, Titin Eka Ardiana ${ }^{2)}$, Wahna Widhianingrum ${ }^{3)}$ \\ ${ }^{1}$ Fakultas Ekonomi Universitas Muhammadiyah Ponorogo \\ Email: titin_ardiana@yahoo.co.id \\ ${ }^{2}$ Fakultas Ekonomi Universitas Muhammadiyah Ponorogo \\ Email: nanangcendriono@gmail.com \\ ${ }^{3}$ Fakultas Ekonomi Universitas Muhammadiyah Ponorogo \\ Email:wwahna@yahoo.com
}

\begin{abstract}
Abstrak : Kondisi permasalahan dan kemiskinan yang dihadapi rumah tangga dengan kepala rumah tangga perempuan secara umum lebih kronis dibanding dengan kepala rumah tangga lakilaki. KRTP tidak hanya mengalami permasalahan di sektor ekonomi, tetapi juga problematika psikologis, sosial, dan budaya. Kebutuhan untuk mendapatkan jalan keluar dari perangkap kemiskinan tidak cukup melalui fasilitas akses ekonomi tetapi memerlukan dukungan interaksi secara intensif dari figur yang secara keseharian sudah dikenal, dinilai mampu memberikan perlindungan, berkelanjutan, serta memiliki legitimasi sosial. Figur tersebut yang selanjutnya menjadi mothercare atau layaknya sebagai sosok ibu atau orang tua yang memiliki kepedulian yang tinggi, menjadi simpul interaksi dan berbagi antar KRTP sehingga akan memupuk harapan serta semangat untuk berjuang bersama-sama dalam upaya keluar dari kemiskinan sesuai dengan kemampuan yang dimiliki. Dalam pengabdian masyarakat ini yang menjadi mitra adalah Pendamping Desa Program Penanggulangan Feminisasi Kemiskinan (PFK) 2017 Kabupaten Madiun. Sasaran 18 mothercare merupakan pendamping desa yang membantu KRTP dalam pengelolaan bantuan Jalin Matra Feminisasi kemiskinan. Mothercare selama ini telah terbukti menjadi relawan pemberdayaan keluarga, oleh karena itu perlu dioptimalkan perannya untuk melakukan pendampingan dan pemantauan terhadap pelaksanaan program sekaligus perkembangan usaha KRTP. Pelaksanaan Pelatihan Akuntansi dan Manajemen khususnya bagi Mothercare yang dilakukan dengan menggunakan metode ceramah, tutorial, dan diskusi serta memberikan motivasi kepada mothercare tersebut. Pemahaman terhadap akuntansi, wirausaha dan motivasi diharapkan akan membantu pengelola bantuan dan penerima bantuan Program Jalin Matra untuk mengelola sumber dana dan penggunaan secara cermat dan efisien sehingga pengelola bantuan dan penerima bantuan Program Jalin Matra dapat berkembang lebih baik dan dapat meningkatkan perekonomian masyarakat desa khususnya di Kabupaten Madiun.
\end{abstract}

Keyword : kepala rumah tangga perempuan, mothercare

\section{PENDAHULUAN}

Permasalahan kemiskinan secara keseluruhan menjadi perhatian Pemerintah Provinsi Jawa Timur, namun secara khusus saat ini mencermati adanya peningkatan populasi perempuan yang hidup di bawah garis kemiskinan serta semakin tumbuh dan akutnya kondisi kemiskinan yang terjadi pada rumah tangga dengan kepala rumah tangga perempuan. Fenomena yang sering 
dikenal sebagai feminisasi kemiskinan atau kemiskinan yang semakin berwajah perempuan tersebut memerlukan upaya khusus dalam rangka penanganannya.Kerentanan kemiskinan yang dialami oleh perempuan juga ditunjukkan oleh data Badan Pusat Statistik tahun 2012 antara lain dari bidang pendidikan yang dilihat dari persentase penduduk nasional penduduk 10 tahun ke atas yang belum pernah sekolah menurut jenis kelamin. Persentase penduduk perempuan usia 10 tahun ke atas yang tidak belum pernah sekolah pada tahun 2012 lebih besar dari pada laki-laki.

Atas dasar permasalahan tersebut, Pemerintah Provinsi Jawa Timur membuat program untuk menangani kemiskinan perempuan, terutama bagi rumah tangga yang Kepala Rumah Tangga Perempuan (KRTP) melalui Program Penanggulangan Feminisasi Kemiskinan. Program tidak hanya sebagai upaya jangka pendek untuk memberikan bantuan kepada KRTP tetapi terlebih daripada itu adalah sebagai program yang berkelanjutan dalam rangka untuk mengantisipasi adanya perangkap kemiskinan (poverty trap) pada KRTP.

Kondisi permasalahan dan kemiskinan yang dihadapi rumah tangga dengan kepala rumah tangga perempuan secara umum lebih kronis dibanding dengan kepala rumah tangga laki-laki. KRTP tidak hanya mengalami permasalahan di sektor ekonomi, tetapi juga problematika psikologis, sosial, dan budaya. Kebutuhan untuk mendapatkan jalan keluar dari perangkap kemiskinan tidak cukup melalui fasilitas akses ekonomi tetapi memerlukan dukungan interaksi secara intensif dari "figur" yang secara keseharian sudah dikenal, dinilai mampu memberikan perlindungan, berkelanjutan, serta memiliki legitimasi sosial. Figur tersebut yang selanjutnya menjadi "mother care" atau baiknya sebagai sosok ibu atau orang tua yang memiliki kepedulian yang tinggi, menjadi simpul interaksi dan berbagi antar KRTP sehingga akan memupuk harapan serta semangat untuk berjuang bersama-sama dalam upaya keluar dari kemiskinan sesuai dengan kemampuan yang dimiliki.

Kegiatan PFK adalah satu dari tiga kegiatan Jalinmatra selain Bantuan Rumah Tangga Sangat Miskin, dan Penanggulangan Kerentanan Kemiskinan. Melalui kegiatan PFK, Kepala Rumah Tangga Perempuan (KRTP) atau "Janda Produktif" akan diberi modal usaha untuk membantu mendorong ketahanan sosial ekonomi, memenuhi kebutuhan hidup dasar, memotivasi berusaha (need for achivement) dan kemampuan (litle skill) dalam upaya meningkatkan kesejahteraannya.

Kegiatan PFK juga melibatkan kader PKK di masing-masing daerah yang diposisikan sebagai "Mother Care" program Jalin Matra. Selain sudah memiliki legitimasi sosial, Jejaring PKK sudah menjangkau kepada keluarga-keluarga secara langsung, karena telah terbentuk kelompok-kelompok PKK RW, RT dan kelompok Dasa Wisma. Mothercare adalah Kader PKK yang berperan aktif dalam membantu KRTP mulai dari perencanaan, pengelolaan dan manajemen pemasaran supaya KRTP bisa berkembang. Keberlanjutan pendampingan itu penting dipikirkan sekaligus diimplementasikan dan ini membutuhkan peran serta mothercare selaku ujung tombak pendampingan. Pendampingan tidak hanya selesai dalam administrasi dan mekanistik tahun pelaksanaan program, tetapi juga dalam pengembangan usaha KRTP. Oleh sebab itu diperlukan inovasi dari mothercare serta fasilitasi jejaring usaha RTS dalam upaya peningkatan kapasitas usaha dari bantuan yang telah diterima. 


\section{METODE PENELITIAN}

Khalayak sasaran yang dipilih adalah pengabdian masyarakat terhadap Mothercare Desa penerima bantuan Jalin matra Feminisasi Kemiskinan Provinsi Jawa Timur tahun 2017 yang terdiri dari 18 Mothercare dan tersebar di 6 Kecamatan dan 16 Desa. Sasaran 18 mothercare tersebut merupakan pendamping desa yang membantu KRTP dalam pengelolaan bantuan Jalin Matra Feminisasi kemiskinan. Mothercare selama ini telah terbukti menjadi relawan pemberdayaan keluarga, oleh karena itu perlu dioptimalkan perannya untuk melakukan pendampingan dan pemantauan terhadap pelaksanaan program sekaligus perkembangan usaha KRTP.

Mothercare diharapkan adalah orang yang paling paham dan paling dekat dengan kondisi KRTP, sehingga dengan didampingi kader, program ini diharapkan akan lebih optimal sesuai dengan mekanisme, sistem serta prosedur yang ditentukan. Pendampingan dilakukan dengan menggunakan pendekatan mikro per rumah tangga serta kelompok karena masing-masing KRTP memiliki karakteristik yang khusus tidak hanya pada aspek ekonomi tetapi juga sosiokultural dan psikologis. Pelaksanaan kegiatan Pengabdian Pada Masyarakat ini dilakukan dengan menggunakan metode ceramah, tutorial, dan diskusi.

\section{HASIL DAN PEMBAHASAN}

Maksud pelaksanaan Program Jalin Matra Penanggulangan Feminisasi Kemiskinan di Kabupaten Madiun adalah peningkatan ketrampilan usaha para penerima bantuan. Tujuan Jalin Matra Penanggulangan Feminisasi Kemiskinan antara lain :

1) Memberikan akses interaksi dan perlindungan terhadap Kepala Rumah Tangga Perempuan melalui optimalisasi peran kader TP-PKK sebagai mothercare bagi KRTP.

2) Memperluas akses Rumah Tangga sasaran dengan Kepala Rumah Tangga perempuan terhadap usaha produktif untuk peningkatan aset usaha/ pendapatan keluarga.

3) Membantu mendorong ketahanan sosial ekonomi rumah tangga untuk memenuhi kebutuhan hidup dasar.

4) Mendorong motivasi berusaha dan kemampuan KRTP dalam rangka meningkatkan kesejahteraannya.

Lokasi kegiatan pengabdian masyarakat adalah di Kabupaten Madiun yang menerima bantuan Jalin Matra Feminisasi Kemiskinan Provinsi Jawa Timur tahun 2017 yang terdiri dari 16 desa dan tersebar di 6 Kecamatan.Lokasi tersebut berdasarkan Pemutakhiran Basis Data Terpadu (PBDT) Tahun 2015 Desil 1 berdasarkan kriteria sasaran diatas dengan ketentuan :

1) Lokasi Jalin Matra Penanggulangan Feminisasi Kemiskinan tahun 2017 ditentukan Pemerintah Provinsi Jawa Timur dengan mempertimbangkan usulan dari Pemerintah Kabupaten.

2) Lokasi Jalin Matra Penggulangan Feminisasi Kemiskinan Provinsi Jawa Timur 2017 berada di 16 Desa dan 6 Kecamatan

Dengan bantuan Program Jalin Matra Feminisasi Kemiskinan Provinsi Jawa Timur tahun 2017 saya bersama team Dosen Fakultas Ekonomi Universitas Muhammadiyah Ponorogo akan mengadakan pengabdian masyarakat terhadap Mothercare Desa penerima bantuan Jalin matra Feminisasi Kemiskinan Provinsi Jawa Timur tahun 2017 yang terdiri dari 18 Mothercare dan tersebar di 6 Kecamatan dan 16 Desa. 
Sasaran 18 mothercare tersebut merupakan pendamping desa yang membantu KRTP dalam pengelolaan bantuan Jalin Matra Feminisasi kemiskinan. Mothercare selama ini telah terbukti menjadi relawan pemberdayaan keluarga, oleh karena itu perlu dioptimalkan perannya untuk melakukan pendampingan dan pemantauan terhadap pelaksanaan program sekaligus perkembangan usaha KRTP. Mothercare diharapkan adalah orang yang paling paham dan paling dekat dengan kondisi KRTP, sehingga dengan didampingi kader, program ini diharapkan akan lebih optimal sesuai dengan mekanisme, sistem serta prosedur yang ditentukan. Pendampingan dilakukan dengan menggunakan pendekatan mikro per rumah tangga serta kelompok karena masing-masing KRTP memiliki karakteristik yang khusus tidak hanya pada aspek ekonomi tetapi juga sosiokultural dan psikologis.

Adapun pengabdian masyarakat terhadap 18 mothercare meliputi:

1) Pelatihan Akuntansi.

2) Pelatihan kewirausahaan.

3) Motivator mothercare.

Dengan adanya pengabdian masyarakat tersebut diharapkan mothercare benar-benar bisa memotivasi KRTP dalam mengelola usaha yang mendapatkan bantuan dari Program jalin matra Feminisasi Kemiskinan Provinsi Jawa Timur 2017. Keberlanjutan bantuan Program Jalin Matra PFK bisa dilaksanakan mothercare melalui beberapa segi misalnya :

1) Fasilitasi pengembangan usaha produktif KRTP dan atau Pokmas KRTP.

2) Fasilitasi penguatan modal sosial KRTP melalui penguatan kelompok yang ditumbuhkan dari kesadaran partisipatoris.

3) Pengembangan jejaring usaha, baik disektor hulu, hilir, maupun fasilitasi permodalan dan pengembangan kapasitas sumber daya manusia KRTP.

Pelaksanaan kegiatan Pengabdian Pada Masyarakat ini dilakukan dengan menggunakan metode ceramah, tutorial, dan diskusi.Adapun sistematika pelaksanaan kegiatan pengabdian ini adalah sebagai berikut:

Langkah 1 (Metode Ceramah):

Peserta diberikan motivasi agar memiliki kemauan untuk menggunakan akuntansi dalam kegiatan pendamping desa yaitu mothercare. Selain itu, peserta diberikan materi gambaran umum tentang akuntansi dan peran penting akuntansi bagi Pendamping Desa Atau Mothercare. Langkah pertama diselenggarakan selama 1 jam.

Langkah 2 (Metode Tutorial):

Peserta pelatihan diberikan materi akuntansi dan manajemen. Langkah kedua diselenggarakan selama 3 jam.

Langkah 3 (Metode Diskusi):

Peserta pelatihan diberikan kesempatan untuk mendiskusikan permasalahan yang berkaitan dengan keuangan pendamping desa atau mothercare yang selama ini dihadapi. Langkah ketiga diselenggarakan selama 1 jam. 
Motivator bagi mothercare

1) Pendamping Desa atau mothercare difasilitasi untuk memberikan penyuluhan, bimbingan, konsultasi, asistensi, pelatihan dan fasilitasi teknis kepada penerima bantuan agar dapat memanfaatkan dan mengembangkan bantuan usaha yang diberikan secara optimal.

2) Pendamping Desa atau mothercare berbentuk pembinaan usaha, peningkatan SDM, manajemen, teknologi, akses pemasaran maupun informasi-informasi lain sesuai kebutuhan, dan dapat pula berbentuk resolusi konflik, yakni penanganan terhadap permasalahan yang terjadi.

3) Pendamping Desa atau mothercare dapat dilaksanakan oleh Sekretariat Provinsi, Kabupaten, Desa, SKPD terkait, dan atau stakeholder yang dibantu pendamping Kabupaten.

4) Pendamping Desa atau mothercare pasca program diserahkan kepada Pemerintah Desa dan Pemerintah Kabupaten.

5) Perguruan Tinggi dan LSM diharapkan dapat berperan aktif dalam bermitra dengan Pendamping Desa atau mothercare pasca Pelaksanaan Jalin Matra PK2 melalui kegiatan Tri Dharma Perguruan Tinggi atau melalui pola binaan.

\section{SIMPULAN DAN SARAN}

\subsection{Simpulan}

Kegiatan pelatihan akuntansi dan manajemen bagi mothercare penerima bantuan KRTP Jalin Matra Kabupaten Madiun untuk meningkatkan kinerja keuangan pemerintahan desa dan kegiatan usaha bagi penerima bantuan agar bisa berjalan dengan lancar. Semua peserta antusias mengikuti acara hingga selesai dan merasakan manfaat pelatihan bagi kemajuan usaha mereka.

\subsection{Saran}

Pelatihan serupa dapat dilaksanakan kembali dengan peserta (audience) yang lebih banyak atau luas, dan dengan topik lainnya. Di samping itu fasilitas untuk presentasi seperti LCD, pengeras suara sebaiknya diperiksa kembali sebelum acara dilaksanakan.

\section{DAFTAR PUSTAKA}

Anonim. 2016. www.madiunkab.go.id

Anonim. 2016. Info madiun. Kondisi ekonomi kabupaten madiun.com

Bapemas Provinsi Jawa Timur. (2016) Pedoman Umum Penanggulangan Kerentanan Kemiskinan. Pemerintah Provinsi Jawa Timur. Surabaya.

Handoko. 2009. Statistik Kesehatan, Belajar Mudah Teknik Analisis Data dalam Penelitian Kesehatan. Mitra Cendekia Press. Jakarta. 